\title{
Phenomena of Religious Consciousness in the Genesis of Neo-Vedantism: Understanding in the Study of Bengal Renaissance Philosophical Thought ${ }^{1}$
}

\author{
Tatiana G. Skorokhodova \\ Penza State University \\ tgskorokhod@gmail.com
}

\begin{abstract}
The influences of the phenomena of religious consciousness on the thinking and philosophy of Modern India are described in the article, based on the Bengal Renaissance works of the nineteenth and early twentieth centuries, especially those of the inaugurator Rammohun Roy. He created the basic foundations of Neo-Vedanta philosophy predominantly owing to the special phenomena of religious consciousness. The basic phenomena are primordial religious experience and the experience of contemplation and understanding of an Other religion (Islam and Christianity). Derivative phenomena are "monotheistic revolution" (term by G. Pomerants) and dialogue of religions in personal consciousness. Opening the resemblance of Vedanta and other religious traditions' meanings to dialogue helped to achieve a new interpretation of the darśana. The novelty of Neo-Vedantism lies in the appearance of mighty ethical and social vectors of thinking. The combination of the aforesaid phenomena created the method of philosophising - free dialogue between one's own tradition and another in order to enrich indigenous thought.
\end{abstract}

Keywords: Vedanta, Neo-Vedantism, the Bengal Renaissance, Rammohun Roy, religious consciousness, understanding of other religion, dialogue

Słowa kluczowe: Wedanta, Neowedanta, bengalski renesans, Rammohun Roy, świadomość religijna, zrozumienie innej religii, dialog

The influence of religion on the genesis and development of modern Indian philosophy in the nineteenth and early twentieth century is a significant theme in research. On the one hand, the Western impact on Indian thought and culture in the colonial

${ }^{1}$ The study is supported by the Russian Science Foundation grant "Indian Philosophy in the History of World Philosophy Context: the Meanings' Translation Problem,” project no. 16-18-10427. 
epoch included the influence of Christianity in different forms - from missionary activity to intellectual reflection on biblical texts. On the other hand, through the ages the space of Indian civilisation has been a special place of birth and growth of religions and of communications between indigenous and foreign (Zoroastrianism, Islam) Eastern religions. Modernity in India became a time for creating philosophical thought, developing in dialogue with Western and Eastern cultural - especially religious - thought.

There are two aspects in the influence of religion on the development of Indian philosophical thought: external and internal. The external influences are the Christian religion, its scripture and religious thought, Islam, as well as indigenous religious tradition and the ideas of Brahmanism. Western and Eastern external influences are sufficiently depicted in literature. ${ }^{2}$ The most valuable works on the subject are by David Kopf and Wilhelm Halbfass. Kopf explicated Christian influences on Bengal Brahmo intellectuals in his well-documented book; especially inter-relations between Unitarianism and Modernist thought and reform practice in the Brahmo Samaj. ${ }^{3}$ Halbfass described the process of destruction of traditional Indian xenology by a multitude of Western influences, including religious ones, and represented new Indian thought and Neo-Hinduism as the product of an understanding of European culture and thought in connection with the understanding of Hindu tradition. ${ }^{4}$

The internal influences of religion on Indian thought in Modernity connected with the inner world of the thinker, who experienced different feelings and thoughts in his religious life, in his "life-world" (E. Husserl). The experience of Hindu confession, religious practices, identity with Hindu religious tradition, and a relationship with other religions are internal influences. These exist in the religious consciousness of modern Indian thinkers, and are an important factor in the emergence of new philosophical thought, especially so-called Neo-Vedantism. But the aforementioned influences as well as religious consciousness are insufficiently depicted in literature on the history of modern Indian philosophy. Halbfass pays attention to the selfconsciousness of the new Indian intellectual, describing the hermeneutic situation of Rammohun Roy. ${ }^{5}$ Other scholars offer brief remarks on the internal world of Indian thinkers of the epoch. Meanwhile, the basic foundations of Neo-Vedantism were created predominantly owing to the special phenomena of religious consciousness, which had an influence on philosophical development in modern India.

A problem lies in the necessity to supplement the thoroughly described external influences on philosophical development in modern India with a description of special phenomena in the religious consciousness of Indian intellectuals. In my opinion,

${ }^{2}$ See: V.S. Naravane, Modern Indian Thought, New York 1964; K. Satchidananda Murthy, Philosophy in India: Traditions, Teachings and Research, Madras 1986; G.S.S. Sreenivasa Rao, Vedanta: Some Modern Trends, Bombay 1982, A.P. Sen, Hindu Revivalism in Bengal: 1872-1905: Some Essays and Interpretation, Delhi 1993, idem, Exploration in Modern Bengal (c. 1800-1900): Essays in Religion, History and Culture, Delhi 2010.

${ }^{3}$ D. Kopf, Brahmo Samaj and Shaping of Modern Indian Mind, Princeton 1979, pp. 3-41.

${ }^{4}$ W. Halbfass, India and Europe. An Essay of Philosophical Understanding, Albany 1988, pp. 219 221.

Ibidem, pp. 203-208. 
the problem is of a methodological nature, and therefore, philosophical research can be used to solve it.

The purpose of my research is to provide a theoretical description of the special phenomena of religious consciousness and its influence on the genesis of Neo-Vedanta philosophy. These phenomena were borne by Bengal thinkers from Rammohun Roy and Debendranath Tagore to Swami Vivekananda and Aurobindo Ghose. To achieve the objective of the research, a phenomenological approach was selected for a description of internal sources of the movement of philosophical thought. Firstly, the approach helps to consider the genesis of Neo-Vedantism within the broad context of an epoch. Secondly, it claims to distract from all existing interpretations and to return to an experience and position of persons-subjects of the epoch (Indian intellectuals). The experience and position are considered as reflected in their texts, taken as primary sources. Thirdly, the phenomenological approach aims to determine and theoretically describe the phenomena of religious consciousness based on biographical data and textual hermeneutics.

Generally, the emergence of Neo-Vedantism was connected with the Bengal Renaissance of the nineteenth and early twentieth century, which was the epoch of national-cultural renaissance in colonial British India. ${ }^{6}$ The renaissance processes began in the most developed province of colonial India, Bengal, which was situated on the periphery of traditional society and, owing to the British colonial conquest and rule of the East India Company (EIC), had become a meeting point of Indian and Western cultures.

On the one hand, the cultural policy of the EIC government stemming from Warren Hastings was oriented towards studying of Indian languages, culture and history for administrative as well as educational and scientific purposes. ${ }^{7}$ As Kopf writes, "[t]he implementation of Hastings's policy in the growing cosmopolitan centre of Calcutta contributed enormously to the awakening of the Bengali mind." ment's support for traditional learning and languages (Sanskrit, Persian and Arabic and others) as well as British Orientalism were important factors influencing the Modern Western-educated elite (bhadralok) in their turning to the Indian cultural - in particular philosophical - heritage embodied in sacred texts (from the Vedas and Upanishads to dharmașastras and "Bhagavadgita"). ${ }^{9}$ Among the orientalists were the first critics of

${ }^{6}$ See: D. Kopf, British Orientalism and Bengal Renaissance, Berkeley 1969; J. Justyński, Myśl społeczna i polityczna renesansu indyjskiego, od Rama Mohana Raya do Rabindranata Tagore, Warszawa 1985; S. Dasgupta, The Bengal Renaissance: Identity and Creativity from Rammohun Roy to Rabindranath Tagore, Delhi 2012; idem, Awakening: The Story of the Bengal Renaissance, Noida 2011; T.G. Skorokhodova, Bengal'skoe Vozroždenie. Očerki istorii sociokulturnogo sinteza v indijskoj filosofii Novogo vremeni, St. Petersburg 2008 (T.G. Skorokhodova, The Bengal Renaissance: Essays on History of Socio-cultural Synthesis in Modern Indian Philosophical Thought); eadem, The Bengal Renaissance: Idea, Term and System of Symbolical Description, "Modern Research Studies: An International Journal of Humanities and Social Sciences" 2015, December, vol. 2, issue 4, pp. 738-768, http://files.hostgator. co.in/hostgator201172/file/2015020404.pdf [access: 26.06.2017].

${ }^{7}$ See: S. Dasgupta, Awakening: The Story of the Bengal Renaissance, op. cit., pp. 7-41.

${ }^{8}$ D. Kopf, British Orientalism and Bengal Renaissance, op. cit., p. 19.

${ }^{9}$ See: S. Dasgupta, The Bengal Renaissance: Identity and Creativity from Rammohun Roy to Rabindranath Tagore, op. cit., pp. 21-38. 
traditional society and its institutions such as sati (concremation of the Hindu widow alive on her husband's funeral pyre), child marriages etc. - H.T. Colebrook and then W. Carey. ${ }^{10}$ Moreover, British colonial rule had brought education and science to India through its institutions. European rationalist philosophy, the achievements of science and spiritual searching in the religious sphere were the stimuli for Indians to have European education and imbibe new, different cultural achievements and models of thinking. But all the aforesaid factors were only one aspect of the Bengal awakening.

On the other hand, the Bengal elites possessed a positive and developed cultural indigenous background for meeting and dialogue with the West. The traditional Sanskrit education gave them a knowledge of Hindu scriptures and classical philosophical schools. Moreover, many representatives of high-caste Hindu elites had a traditional Muslim education, and Persian language and culture were an integral part of their own lives. ${ }^{11}$ Consequently, the Bengal literati were included in a process of studying of Indian texts and culture in the newly established Fort William College (1800). ${ }^{12}$ And later, owing to both Western and Sanskrit educated thinkers and reformers, the intensive cultural dialogue between Indian and Western thought and culture began, and was expanded for the awakening and modern development of Indian society. Essentially, the Bengal Renaissance was a time of reconsideration of Indian traditional heritage in the light of European rationalism and Western innovations. The renaissance thinkers searched for an ideal variant of Indian-Western synthesis in all spheres of socio-cultural life for adequate integration into Modernity.

Briefly, the content of the Bengal Renaissance could be described as four conventional aspects of thought and practice.

1. Religious renaissance represented a search for true faith and humanity in opposition to orthodoxy and dehumanisation of socio-religious life.

2. Social renaissance based on the idea of existence of social problems originated from the collision between ethical norms and human behaviour. Bengal's reformers fought against different forms of social alienation - legal (discrimination), economic (poverty), social (caste and gender inequality) and others - for a worthy life for the populace. Moreover, Bengal thinkers tried to form the project of social development based on the idea of civil society.

3. Political renaissance was embodied in the political and legal activity of the new social group and stratum. Bengal intellectuals had created a new political philosophy, impressed as they were Western political values and institutions, and were simultaneously strict critics of British colonial rule in India.

4. Cultural renaissance is the process of creation of modern Bengal culture based on a synthesis of national and universal, regional and pan-Indian, indigenous and ancient traditions with new ideas of the modern epoch. ${ }^{13}$

${ }^{10}$ D. Kopf, British Orientalism and Bengal Renaissance, op. cit., pp. 39-41; M. Dewanji, William Carey and Indian Renaissance, Delhi 1996, pp. 69-76.

${ }^{11}$ D. Kopf, British Orientalism and Bengal Renaissance, op. cit., p. 60.

${ }^{12}$ See: ibidem, pp. 56-62.

${ }_{13}$ Summarised from: T.G. Skorokhodova, The Bengal Renaissance: Idea, Term and System of Symbolical Description, op. cit., pp. 761-762. 
The Bengal Renaissance meant the broad context of the genesis and development of Neo-Vedantism. The religious renaissance can be described as its peculiar context, because religion was an important factor in the reconsideration of national spiritual heritage and searching for synthesis.

The development of the new, modern philosophy began in an encounter between traditional schools (darśana) - first of all Vedanta - and ideas and conceptions raised and grounded by new thinkers. The new interpretation of classical darśana according to the spiritual, cultural and social needs of the nineteenth and twentieth centuries allows us to refer to the trends of thought by the conventional term "Neo-Vedantism." 14 Based on reconsidered traditional Vedanta, the philosophy of the epoch is predominantly religious, including social thought. The religious character of modern Indian philosophy cannot be explained only by reference to the firm religiosity of Hindus in general, and the novelty of the reconsidered Vedanta cannot be explained mainly by the influence of Western rationalism and culture or by striving for the revival of ancient Upanișadic ideas in Modernity. All aforementioned explanations are true, but the explanatory approach could be complemented by a phenomenological approach for understanding the genesis of Neo-Vedantism through the religious consciousness of its thinkers. Their religious consciousness was non-trivial, unorthodox and broad, which was why it greatly influenced their thinking and philosophy.

The history of Neo-Vedantism begins from theological works by Rammohun Roy (1772-1833) - philosopher, religious and social reformer, enlightener and politician, regarded as the "Father of Modern India" and "inaugurator of the Bengal Renaissance." ${ }^{15} \mathrm{He}$ was the first thinker to search for an Indian-Western synthesis and ground the foundations of the new philosophy. Not only was he the first Neo-Vedantist thinker of modern India, but his primordial spiritual and philosophical becoming proceeded in parallel and independent of the cultural and educational processes in Bengal. He had a two-fold traditional - Muslim and Sanskrit - education (from 9 to 18 years old; 1781-1790), but before maturity he did not know English. Rammohun was an autodidact in English language and Western culture, and before 1815 was not connected with representatives of government-supported institutions such as the Asiatic Society in Calcutta or Fort-William College. He wrote and published his own Vedantic works in 1815-1818, before his involvement in intensive discussions with Christian missionaries of Serampur as well as interaction with British Unitarians. In this sense, Rammohun Roy's religious consciousness is the most representative and exclusive example among thinkers of Neo-Vedanta. Besides, the understanding of his religious consciousness helps to deepen the interpretation of the origins and novelty of Neo-Vedantism.

${ }^{14}$ See, for example: V.S. Kostûčenko, Klassičeskâ̂ vedanta i neo-vedantizm, Moskva 1983 (V.S. Kostyuchenko, Classical Vedanta and Neo-Vedantism); S.L. Malhotra, Social and Political Orientations of Neo-Vedantism, Delhi 1970; B. Mukerji, Neo-Vedanta and Modernity, Varanasi 1983; S.N. Sharma, A Critical and Comparative Re-evaluation of Ethics of the Neo-Vedanta, Moradabad 1992.

15 See: A.P. Sen, Rammohun Roy: A Critical Biography, New Delhi 2012; T.G. Skorokhodova, Rammohan Ray, rodonachalnik Bengal’skogo Vozroždeniâ. Opyt analitičeskoj biografii, St. Peterburg 2008 (T.G. Skorokhodova, Rammohun Roy: The Founder of the Bengal Renaissance (An Experience of Analytical Biography)); B.N. Dasgupta, The Life And Times Of Rajah Rammohun Roy, Delhi 1980. 
The study of biographical data along with religious works by Rammohun Roy helped to make apparent the characteristics of his pure religious experience and to denote the main phenomena of religious consciousness. The primary sources are Tuhfat-ul-Muwahhidin ("A Present to the Believers in One God," 1804) and the works on the Vedanta (Abridgement of Vedanta, English translations of Isa, Kena, Katha and Mundaka Upanishads and others). Following study, four phenomena were marked theoretically as influencing the thinking.

Conventionally, there are two groups of phenomena in the religious consciousness of the Bengal religious thinkers. The first group includes basic phenomena such as primordial religious experience and the experience of contemplation and understanding of an Other religion. The second group contains derivative phenomena of religious consciousness such as "monotheistic revolution" (Grigory Pomerants's term) and dialogue of religions in personal consciousness.

Religious experience is treated as senses, thought and conditions in the process of religious practice (prayer, worship, meditation etc.) and after. It can be presented as the process of a human's dialogue with High Reality, which is revealed to the soul of believers in Nature, Culture and Society - above all in relation to Others.

Thinking and philosophising on God, humans, the world and society is one of the results of religious experience.

The primordial religious experience of Rammohun Roy was connected with traditional Hinduism. He was born and brought up in a Vaishnav family, and in early childhood was very devout. Vaishnav tradition has a strict monotheist tradition in worship of Vishnu as a personal deity in some image (Krishna, Rama) and exalted emotional worship (bhakti). Rammohun's mother cultivated religious exaltation, scrupulous ritual practice and regular worship. Sophia Dobson Collet writes that the child Rammohun's "reverence for Vishnu was at one time so great that he would not even take a draught of water without first reciting a chapter of the Bhagavata Purana" and, "for the attainment of knowledge and wisdom," he had, at great expense, a certain ceremony performed for him 22 times, called Purasharan, consisting in a repetition of the name of a deity, accompanied with burnt offerings. ${ }^{16}$

From the primordial childish experience of the sacred world grew a strong interest in spiritual life. The interest usually combines with intellectual study, which was encouraged in high-caste families. The foundation of the study was traditional Sanskrit education, which created the so-called "learned man" in Hindu society. Sanskrit education is obligatory for Brahmin, and Rammohun Roy was educated in the famous centre of Sanskrit learning Benares. But Rammohun Roy is most representative as well as exclusive, because the future reformer and thinker had a dual traditional education. His first was a traditional Islamic education in Patna. In Bengal, Islamic education opened broad career opportunities. The first education was at the same time his first experience of contemplation and understanding of an Other religion. Islamic monotheistic spirituality was more serious and sublime in comparison with the familiarity of emotional and ritualistic worship to Krishna in his parents' home.

${ }^{16}$ S.D. Collet (and F.H. Stead), The Life and Letters of Raja Rammohun Roy, D.K. Biswas, R.C. Ganguli (eds.), Calcutta 1962, p. 5. 
The impressions made by Islam were so deep that Rammohun's mother insisted upon sending her son to Benares for a Sanskrit education.

Rammohun was impressed by the Islamic principle of monotheism (at-tawhīd) and negation of polytheism (shirk) in the motto "There is no god but God." It was fully opposed to Hindu polytheism. Studying the Koran in the original Arabic, Rammohun's "eyes seem to have been, for the first time, opened to the errors of Hindu idolatry." 17 The attention to the spiritual essence of the faith, absence of hierarchy of mediators between believer and God, and equality of believers were also impressive. Evidently, instruction in Patna was the first source of Rammohun's doubts in preference of special religious path for another. The second source was education in Benares, where there existed an influential tradition of advaita-vedanta - non-dualist orthodox darśana. The advaitist recognition of Brahman (Absolute) as one true reality was the Hindu analogue of monotheism for Rammohun, and in some sense, another religious philosophy for Bengal Vaishnav tradition. Therefore, the experience of understanding of other religions by Rammohun can be interpreted as an impulse for deep consideration on the essence, the spirit and the letter of religion. Later to this consideration was added Rammohun's study and understanding of Christianity, based on reading and exegesis of the Bible in the original languages. The consequence of his considerations was the first derivative phenomenon of his religious consciousness - "monotheistic revolution."

"Monotheistic revolution" is a term offered by the Russian religious philosopher Grigory Pomerants to mark the appearance of one universal faith in an invisible, omnipresent and omnipotent God. ${ }^{18}$ But if Pomerants applied the term to some peoples or societies, I propose to apply it to a concrete person, bearing in mind the specific Indian circumstances. In the Indian Renaissance the monotheistic revolution came from a combination of primordial religious experience with contemplation and understanding of other religion in the personal consciousness of the thinkers of the epoch. Rammohun Roy was the first to experience the monotheistic revolution.

Biographers often mentioned a tract against idolatry written by Rammohun in his teens, causing his banishment from the parental home or a large scandal in the family. But there is no text of the tract. I suppose it is identified with his first mature tract Tuhfat-ul-Muwahhidin ("A Present to the Believers in One God," 1804; in Arabic and Persian). The results of the monotheistic revolution were first represented in Tuhfat, where Rammohun proved his rational preference for knowing faith against blind faith. The sentence "that turning generally towards One Eternal Being is like a natural tendency in human beings and is common to all individuals of mankind equally" 19 is a position of a human who had experienced the presence of God. Rammohun proves that "belief only in one Almighty God is the fundamental principle of every religion." ${ }^{20}$ Later, he integrated the main ideas of his first philosophical tract into subsequent works on Vedanta and Hindu religion.

${ }^{17}$ S. Sastri, The History Brahmo Samaj, vol. 1, Calcutta 1919, p. 16.

${ }_{18}$ G.S. Pomeranc, Zapiski gadkogo utënka, Moskva 2012, pp. 262-272 (G.S. Pomerants, Memoirs of Bad Duckling).

${ }_{19}$ R.R. Roy, The English Works, vol. 4, J.C. Ghose (ed.), New Delhi 1982, p. 943.

${ }^{20}$ Ibidem, p. 957. 
As a consequence of the monotheistic revolution, Rammohun founded the experience of both liberty and dialogue of religions. His spiritual revolution turned into a deep intuition of liberty in connection with God, other beings and the world. The intuition was continued in freedom from the strict chains of rites and institutions and freedom for personal spiritual, moral, social and cultural growth of human and society. The monotheistic revolution is the foundation of Rammohun's non-dogmatic philosophising, of his heterodox thinking and freedom of interpretation of Hindu sacred texts.

The phenomenon of dialogue of religions in the thinker's consciousness is derivative of both understanding of other religions and monotheistic revolution. The dialogue can be described as a certain trajectory of the movement of the thought from the initial point, which is concrete pre-understanding of the essence of both the faith and the content of religion. Pre-understanding helps to juxtapose faiths/religions in searching for resemblance of their meanings. The mental space of the juxtaposed religions instigates moving to the other faith's position in order to perceive and understand that of one's faith from the outside. The dialogue of religion brings various results in the religious and social, spiritual and cultural spheres. For example, for Bengal thinkers it was the vindication of Hindu faith, the creation of an attractive reformist image of Hinduism, as well as of all Indian culture.

The dialogue of religions helps to understand the thinker's own religious experience, as well as his religion, his co-religionists and men of different religions. It is also a tremendous stimulus for religious and socio-philosophical thinking, as in the case of most influential intellectuals of Bengal.

Rammohun was the first thinker to build a dialogue of religions in his own consciousness. Essentially, it was a triple dialogue of Hinduism, Islam and Christianity, based on study of sacred texts. Rammohun began the process of the dialogue with the attempt to comprehend the meanings of his own Hindu religion through comparison with Islam and Christianity. He then formed representations about them and, finally, created the images of three religions. Understanding of the meanings and truths of other religions has a positive value.

Primarily, the dialogue of religion began as one between Hinduism and Islam from Rammohun's pre-understanding in Tuhfat: all peoples "agreeing generally in believing in the personality of One Being Who is the source of all that exists and its governor." ${ }^{21}$ Therefore, all religions strive to One God, but are different in terms of doctrines, precepts and forms of worship. Rammohun asserted the truth and primacy of spiritual relations and faith in God and the derivative, socio-genetic character of religious institutions. Created by people, the institutions can be both false and truthful. In other words, his pre-understanding was based on a universalistic view of the essence and core of any religion as the embodiment of the soul's striving to God.

Based on a universalistic approach, Rammohun created a critical method of thinking about any religion, including his own one, for "finding out the true nature of a faith which for so many years has been believed in without enquiry into its truth or

21 Ibidem, p. 943. 
falsehood." ${ }^{22}$ His native religion - Hinduism - was his first object of criticism, because of the growing "belief in supernatural and miraculous things ascribed to heroes and saints. ${ }^{.23}$ Rammohun presented contemporary Hinduism as full of rites, idolatry, superstitious, cruel customs, and socio-religious restrictions, and wanted to find a form of Hinduism with a high monotheistic faith in God and free from historical additions. In Tuhfat, Rammohun firstly juxtaposed the Brahmins' religious tradition and Islam. "Brahmins have a tradition from God that they have strict orders from God to observe their ceremonies and hold their faith for ever" 24 - they were even persecuted and threatened with death by followers of Islam. Following God's order, Muslims killed and persecuted idolaters. Rammohun explains these contradictory precepts as "the fabrications of the followers of religion," only while God claims "gaining the union of all their fellow-creatures without difference in shape and colour or creeds and religions; which is pure devotion acceptable to God." ${ }^{25}$

Later, based on a universalistic approach to the core of any religion as monotheism and its forms of worship and institutions as derivative, Rammohun began to understand Christianity. When he was an officer in the administration of the East Indian Company, Rammohun had mastered English along with Hebrew, Greek, and Latin, as well as having intensive interaction with Serampur Baptist Missionaries. He had read the Old and New Testaments both in the original and in the King James Version (Tyndall's translation). He resolutely rejected the attempts of the Baptist and Anglican clergy to convert him to Christianity. In 1820 he published The Precepts of Jesus, the Guide to Peace and Happiness. This was a compilation of Christ's sayings from the Four Gospels, mainly on faith in God, religion and morality. For a long time, this publication with a preface was the cause of his dispute with missionaries in defence of his understanding of Christianity. ${ }^{26}$

The understanding of the Other and his own religions develops in Rammohun's works as a transition from a perception of one as some completeness (the spirit + sacred texts and doctrines + worship form + institutes) to definition of its essential which relates to a universal spirit of religion. At once, Rammohun criticises all things related to the letter of religion, such as social and institutional derivatives and inventions. Finally, the examined essentials come in the space of a triple dialogue of religions and interact with the ideas of other faiths.

Acting in this way, Rammohun understands, as the essentials of Islam, monotheism and negation of polytheism as well as the idea of merciful God-Creator of the world and human being. He had imbibed the emotional aspect of Islam from Sufism;

${ }^{22}$ Ibidem, p. 946.

${ }^{23}$ Ibidem, pp. 949-950.

${ }^{24}$ Ibidem, p. 954.

25 Ibidem.

${ }^{26}$ See: T.G. Skorokhodova, Ponimanie hristianstva kak Drugoy religii v èpohu Bengal'skogo Vozroždeniâ [in:] "Va, pensiero, sull'ali dorate": iz istorii mysli i kul'tury Vostoka i Zapada: sbornik statej k 70-letiû Evgeniâ Borisoviča Raškovskogo, T.G. Skorokhodova (ed.), Moskva 2010 (T.G. Skorokhodova, Understanding of Christianity as Other Religion in the Bengal Renaissance [in:] "Va, pensiero, sull'ali dorate": From a History of Thought and Culture in East and West. A Collection of Articles in Honour of Eugene B. Rashkovsky's 70th Birthday, T.G. Skorokhodova (ed.)). 
from it derived an idea of personal spiritual experience and inner realisation of faith. Rammohun absorbed Islamic rationality from mu'tazilites, who grounded the free will and supremacy of ethics.

Rammohun understood Christianity as a monotheist religion with a humanistic essence, explained by Christ in the Gospels. The essentials are love for God and one's fellow creatures, high ethics of mercy, compassion and social service. The teaching of Christ addresses all humanity without distinction of faith and leads to happiness, peace and harmony of all mankind. The derivative and non-essential aspects in Christianity for Rammohun are the tenets of the Trinity and Atonement, deification of the historical person of Jesus Christ, components of idolatry in worship, the miracles described in the Gospels and denial of salvation for non-Christians.

In consequence, Rammohun's space of triple dialogue of religion is the space of universal faith in God, and this base helps to find the points of coincidence in meanings and the possibility of mutual understanding between believers of different religions. Rammohun offers to put this possibility into practice and says: "[...] in China, in Tartary, in Europe, and in all other countries, where so many sects exist, all believe the object whom they adore to be the Author and Governor of the universe; consequently, they also must acknowledge, according to their own faith, that this worship is their own."27

By mentally transferring to the position of Islam and Christianity, Rammohun had the opportunity to see popular traditional Hinduism as polytheistic worship of images of god and goddesses, and as heathenism full of irrational practices, superstitions and anti-human rites (such as sati). ${ }^{28}$ There were two general results of the triple dialogue of religion in Rammohun's consciousness. The first was creation of a monotheistic and ethical image of Hinduism ${ }^{29}$ and "invention of the monotheistic movement," ${ }^{30}$ the foundation of the Brahmo Samaj (1828) - the movement and church of monotheist Hindu worship. The second result was the creation of Neo-Vedanta philosophy.

Rammohun refers the vindication of Hinduism as a monotheist and ethical religion to the authority of the ancient sacred texts of the Upanishads and philosophy of Vedanta. He chose the basic text of Vedanta-darśana - Brahma-sutra by Vyasa or Badarayana - and published the Bengal, English and Hindi translation from Sanskrit in 1815-1816 in complete and brief versions. He then published Bengal and English translations of Isa, Kena, Katha and Mundaka Upanishads. Rammohun proclaimed that the Supreme Being "[...] is the subject of discourse in all the Vedas, and

${ }^{27}$ R.R. Roy, The English Works, vol. I, op. cit., p. 136.

${ }^{28}$ For other factors influencing Rammohun's position on the necessity of abolition of sati, see: A. Nandy, Sati: A Nineteenth-Century Tale of Women, Violence and Protest [in:] Rammohun Roy and the Process of Modernization in India, V.C. Joshi (ed.), New Delhi 1975, pp. 168-194.

${ }^{29}$ The idea of monotheism as existed in the Vedas, "the unity of the Godhead" in "Essay on the Vedas," was first maintained by H.T. Colebrook - this fact is noted by Kopf (D. Kopf, British Orientalism and Bengal Renaissance, op. cit., pp. 40-41). But there are no verifiable facts about the influence of Colebrook's work on Rammohun. In my opinion, Islamic monotheism has the most powerful influence on him.

${ }^{30}$ S. Dasgupta, The Bengal Renaissance..., op. cit., p. 39. 
the Vedanta, as well as in the other systems of Theology." ${ }^{\prime 31}$ Therefore, the Hindu practice of worshiping God's attributes must be overcome although "every rite has its derivation from the allegorical adoration of the true Deity." 32

According to Rammohun, the high ethics of the Upanishads corresponds to the purpose of Hindu monotheism, because it was built on the "grand and comprehensive moral principle Do unto others as ye would be done by." ${ }^{33}$ It demands serious transformations in religious and social aspects of Hindu life. This image of ethical and monotheistic Hinduism was laid down as a symbol of faith of the Brahmo Samaj. It is clear from the "Trust Deed of the Brahmo Samaj," legitimising the creed: "the worship and adoration of the Eternal Unsearchable and Immutable Being who is the Author and Preserver of the Universe but not under or by any other name designation or title peculiarly used for and applied to any particular Being or Beings [...]" and "the promotion of the contemplation of the Author and Preserver of the Universe to the promotion of charity, morality, piety, benevolence, virtue, and the strengthening he bonds of union between men of all religious persuasions and creeds. ${ }^{\prime 34}$ Besides, this image of religious tradition is laid down as the foundation of Neo-Vedantism.

The German Indologist Wilhelm Halbfass notes that Rammohun's concern with sacred texts was not solely based upon pragmatic and tactical considerations: "His self-understanding as 'Vedantin' seems to have been genuine. It should also be remembered that the role of the Vedanta as a source of authority was ambivalent in Bengal in the period around 1800. The Navyanyaya was predominant in scholastic teaching, and the systematic study of the Vedanta did not play a conspicuous role." 35 I suppose that his choice of Vedanta and the Vedantist position in religion and philosophy was dictated not only by his instruction in Benares, but by the phenomena of his religious consciousness. These are presented in the common bases of Neo-Vedantism by Rammohun in his works.

1st. Vedanta is a theistic philosophy concerned with High Reality - God/Supreme Being or Brahman. The Absolute is presented as ekamevadvitiyam (one without second, Ch-up. VI, 21). One Supreme Being who is Creator, Preserver and Destroyer of the universe and the Truth (Om Tat Sat). The choice of theism was inspired by the monotheistic revolution and influences of Islamic monotheism as well as Christianity understood as monotheism. Moreover, we can trace how Rammohun turned into the language of Vedantic tradition the general ideas of his tract Tuhfat-ul-Muwahhidin in the introduction to the Abridgement of Vedanta.

2nd. The belief in the Only Supreme Being (Brahman) is intimately connected with knowledge of him, which can be gained both apophatically (through the negation of any characteristics) and through the medium of understanding of His creation. Needed in the knowledge process are revelation of the scriptures and common sense.

${ }^{31}$ R.R. Roy, The English Works, vol. I, op. cit., p. 7.

${ }^{32}$ Ibidem, p. 4.

${ }_{33}$ Ibidem, p. 74.

${ }^{34}$ Ibidem, p. 216.

${ }^{35}$ W. Halbfass, India and Europe. An Essay of Philosophical Understanding, op. cit., p. 214. See also: N. Chaudhuri, Intellectual in India, New Delhi 1967, p. 2. 
Evidently, the religious experience - including mystic contemplation - along with influences of Western Enlightenment rationalism, built the epistemological approach of Rammohun's Neo-Vedanta.

3rd. Worship of God can be in the forms of jnana (knowledge), bhakti (devotion) and ethically good acts for other/fellow-creatures. It is not connected with performance of Brahminical rites and ceremonies. The influence of the triple dialogue of religion is evident in the anti-ritualistic ideas of New Vedanta and turning to ethics as a basis of religious life.

4th. Brahman/Absolute in Vedanta by Rammohun has an ethical character as well as following moral principles - "A command over our passions and over the external senses of the body, and good acts" ${ }^{16}$ is declared as indispensable in the mind's approximation to God. Rammohun appealed to the authority of the Vedas, but this ethical turning point in his Vedanta owed to Christianity and Christ's ethical teachings in mental dialogue of religions - without reference to it. Rammohun's Vedanta offers improvement of the moral qualities of humans and taking care of humanity in human relations. Essentially, new ethics creates the new vector of Vedantic thought - anthropological and social.

5th. Neo-Vedanta begins by rethinking both the relationship between God and humans as well as the human's place in the world, his sufferings and happiness. Rammohun's humanism is religious in the core, because, firstly, God takes care of the human being, and, secondly, the human is intended, according to Rammohun - for "the best road to both temporal and eternal happiness" ${ }^{137}$ and to overcome suffering, especially of social origin. I ascribed these ideas to the mighty influences of Christianity, and partially also Islam. The motif of compassion for the victims of the Hindu social traditional order in Rammohun's philosophy is the effect of Christianity. The compassion as part of Neo-Vedanta growths in active position and help of victims; it is very similar to Christian social ideals (as well as the Islamic ideal of mercy).

The aforesaid influences of the phenomenon of religious consciousness do not mean an absence of succession between indigenous philosophical tradition, of Vedanta and Neo-Vedantic ideas by Rammohun. He had continued the tradition, because he turned to orthodox darśanas recognising the Vedas' authority and chose the most theistic of those concerned with the whole explanation and understanding of Upanișad revelation. The philosopher followed tradition in recognition of the appellation to the Vedas' authority, works and interpretations of Vedanta by Śankkara and partially Ramanuja.

Rammohun's interpretation of Vedanta seems simple, but it is a new interpretation principally owing to the phenomena of the thinker's religious consciousness. The novelty of interpretation was achieved by opening of the resemblance of Vedanta's and other religions' meanings in dialogue. Based on dialogical thinking, Neo-Vedanta helps both high interpretation of native religion and development of religiousphilosophical thought in a non-dogmatic and heterodox spirit. It is obvious in the thought of Rammohun's spiritual inheritors.

\footnotetext{
${ }^{36}$ R.R. Rammohun, The English Works, vol. I, op. cit., p. 14.

${ }^{37}$ Ibidem, p. 71.
} 
In phenomenological terms, we can trace similar phenomena, such as religious experience, understanding of other religions, monotheistic revolution and dialogue of religions in consciousness, in the personality of the Bengal Renaissance thinkers, with many effects and results. The brightest example of these phenomena is Swami Vivekananda.

The combination of four phenomena created the method of philosophising - the dialogue of one's own tradition with others, as well as the freedom of thinking in reference and relations to Other and overcoming the dependency on the orthodox tradition. Free dialogue helps indigenous philosophical tradition to understand and imbibe new ideas and thus to enrich it.

Moreover, the theoretical description of phenomena of religious consciousness allows creation of a methodological model for analysis of religious-philosophical thought. Understanding of the inner sources of the Indian thinker's philosophy could begin from a definition of his religious experience (basic phenomena) to determine the components of derivative phenomena - "monotheistic revolution" and dialogue of religions in consciousness. The thinker created inter-religious dialogue in his mind as capable of broad dialogue with a wide circle of external - Western and Indian ideas, religions and cultures, and to generate new creative philosophy.

\section{References}

Chaudhuri N., Intellectual in India, New Delhi 1967.

Collet S.D. (and Stead F.H.), The Life and Letters of Raja Rammohun Roy, D.K. Biswas, R.C. Ganguli (eds.), Calcutta 1962.

Dasgupta B.N., The Life And Times Of Rajah Rammohun Roy, Delhi 1980.

Dasgupta S., Awakening: The Story of the Bengal Renaissance, Noida 2011.

Dasgupta S., The Bengal Renaissance: Identity and Creativity from Rammohun Roy to Rabindranath Tagore, Delhi 2012.

Dewanji M., William Carey and Indian Renaissance, Delhi 1996.

Halbfass W., India and Europe. An Essay of Philosophical Understanding, Albany 1988.

Justyński J., Myśl społeczna i polityczna renesansu indyjskiego, od Rama Mohana Raya do Rabindranata Tagora, Warszawa-Poznań 1985.

Kopf D., Brahmo Samaj and Shaping of Modern Indian Mind, Princeton 1979.

Kopf D., British Orientalism and Bengal Renaissance, Berkeley 1969.

Kostûčenko V.S., Klassičeskaâ vedanta i neo-vedantizm, Moskva 1983 (Kostyuchenko V.S., Classical Vedanta and Neo-Vedantism).

Malhotra S.L., Social and Political Orientations of Neo-Vedantism, Delhi 1970.

Mukerji B., Neo-Vedanta and Modernity, Varanasi 1983.

Nandy A., Sati: A Nineteenth-Century Tale of Women, Violence and Protest [in:] Rammohun Roy and the Process of Modernization in India, V.C. Joshi (ed.), New Delhi 1975, pp. 168-194.

Naravane V.S., Modern Indian Thought, New York 1964.

Pomeranc G.S., Zapiski gadkogo utënka, Moskva 2012 (Pomerants G., Memoirs by Bad Duckling).

Roy R.R., The English Works, J.C. Ghose (ed.), 4 vols., New Delhi 1982.

Sastri S., The History Brahmo Samaj, vol. 1, Calcutta 1919.

Satchidananda Murthy K., Philosophy in India: Traditions, Teachings and Research, Madras 1986. 
Sen A.P., Exploration in Modern Bengal (c. 1800-1900): Essays in Religion, History and Culture, Delhi 2010.

Sen A.P., Hindu Revivalism in Bengal: 1872-1905: Some Essays and Interpretation, Delhi 1993.

Sen A.P., Rammohun Roy: A Critical Biography, New Delhi 2012.

Sharma S.N., A Critical and Comparative Re-evaluation of Ethics of the Neo-Vedanta, Moradabad 1992.

Skorokhodova T.G., Bengal'skoe Vozroždenie. Očerki istorii sociokulturnogo sinteza v indijskoj filosofii Novogo vremeni, St. Petersburg 2008 (Skorokhodova T.G., The Bengal Renaissance: Essays on History of Socio-cultural Synthesis in Modern Indian Philosophical Thought).

Skorokhodova T.G., Ponimanie hristianstva kak Drugoy religii v èpohu Bengal'skogo Vozroždeniâ [in:] "Va, pensiero, sull'ali dorate”: iz istorii mysli i kul'tury Vostoka i Zapada: sbornik statej k 70-letiû Evgeniâ Borisoviča Raškovskogo, T.G. Skorokhodova (ed.), Moskva 2010, pp. 76-95 (Skorokhodova T.G., Understanding of Christianity as Other Religion in the Bengal Renaissance [in:] "Va, pensiero, sull'ali dorate": From a History of Thought and Culture in East and West. A Collection of Articles in Honour of Eugene B. Rashkovsky's (70th Birthday), T.G. Skorokhodova (ed.) [in Russian]).

Skorokhodova T.G., Rammohan Ray, rodonachalnik Bengal'skogo Vozroždeniâ. Opyt analitičeskoj biografii, St. Peterburg 2008 (Skorokhodova T.G., Rammohun Roy: The Founder of the Bengal Renaissance (Experience of Analytical Biography)).

Skorokhodova T.G., The Bengal Renaissance: Idea, Term and System of Symbolical Description, "Modern Research Studies: An International Journal of Humanities and Social Sciences" 2015, December, vol. 2, issue 4, pp. 738-768, http://files.hostgator.co.in/hostgator201172/ file/2015020404.pdf [access: 26.06.2017].

Sreenivasa Rao G.S.S., Vedanta: Some Modern Trends, Bombay 1982. 